\title{
Healthcare-Associated Pneumonia and Hospital-Acquired Pneumonia: Bacterial Aetiology, Antibiotic Resistance and Treatment Outcomes: A Study From North India
}

\author{
Sandeep Kumar ${ }^{1} \cdot$ Rafi Ahmed Jan $^{1}$ (1) - Bashir Ahmad Fomda ${ }^{2} \cdot$ Roohi Rasool $^{3} \cdot$ Parvaiz Koul $^{1} \cdot$ Sonaullah Shah ${ }^{1}$. \\ Umar Hafiz Khan ${ }^{1}$. Syed Mudasir Qadri ${ }^{1}$. Shariq Rashid Masoodi ${ }^{4}$. Suhail Mantoo ${ }^{1}$. Mudasir Muzamil ${ }^{1}$
}

Received: 1 February 2018 / Accepted: 18 April 2018 / Published online: 25 April 2018

๑) Springer Science+Business Media, LLC, part of Springer Nature 2018

\begin{abstract}
Background Data regarding the comparative profiling of HCAP and HAP from developing countries like India are scant. We set out to address the microbial aetiology, antibiotic resistance and treatment outcomes in patients with HCAP and HAP. Methods 318 consenting patients with HCAP ( $n=165$, aged 16-90 years; median 60 years; 97 males) or HAP $(n=153$; aged 16-85 years; median 45 years; 92 males) presenting to a tertiary care hospital in North India from 2013 to 2015 were prospectively recruited for the study. Data on patient characteristics, microbial aetiology, APACHE II scores, treatment outcomes and mortality were studied. Clinical outcomes were compared with various possible predictors employing logistic regression analysis.

Results Patients in HCAP had more comorbidity. Escherichia coli $(30,18 \%)$ and Acinetobacter baumannii $(62,41 \%)$ were the most commonly isolated bacteria in HCAP and HAP, respectively. Multidrug-resistant bacteria were isolated more frequently in HCAP, only because the incidence of extensively drug-resistant bacteria was markedly high in $\operatorname{HAP}(p=0.00)$. The mean APACHE II score was lower in HCAP $(17.55 \pm 6.406$, range 30$)$ compared to HAP $(19.74 \pm 8.843$, range $37 ; p=0.013)$. The length of stay $\geq 5$ days $(p=0.036)$ and in-hospital mortality was higher in HAP group $(p=0.002)$. The most reliable predictors of in-hospital mortality in HCAP and HAP were APACHE II score $\geq 17$ (OR $=14, p=0.00$; HAP: OR $=10.8$, $p=0.00)$, and septic shock $(\mathrm{OR}=4.5, p=0.00$; HAP: $\mathrm{OR}=6.9, p=0.00)$.

Conclusion The patient characteristics in HCAP, treatment outcomes, bacterial aetiology, and a higher incidence of antibioticresistant bacteria, suggest that HCAP although not as severe as HAP, can be grouped as a separate third entity.
\end{abstract}

Keywords Acinetobacter baumannii $\cdot$ Pneumonia $\cdot$ Bacterial $\cdot$ Drug resistance $\cdot$ Microbial $\cdot$ Escherichia coli $\cdot$ Ventilatorassociated

Name: CHEST Annual Meeting 2016-October 22-26, 2016. Session Title: Pneumonia Diagnosis and Outcomes. Date: October 26, 2016, at 2:45 PM. Location of meeting: LA convention centre, Los Angeles, USA. Name: ATS Annual Meeting 2017-May 19-24, 2017. Session Title: B-61 Bacterial respiratory infections. Thematic Poster Session. Date: May 22, 2017, at 9:15 AM to 4:15 PM. Location of meeting: Walter E Washington convention centre, Washington DC, USA.

Electronic supplementary material The online version of this article (https://doi.org/10.1007/s00408-018-0117-7) contains supplementary material, which is available to authorized users.

Rafi Ahmed Jan

rafiahmedjan@gmail.com

Extended author information available on the last page of the article

\section{Introduction}

Pneumonia is the third leading cause of years of life lost (YLLs) worldwide. Globally, pneumonia was responsible for 2377.7 thousand death for the year 2016. The mortality varies with the social demographic index, from eighth most common cause in high socio-demographic index (SDI) groups to the most common cause of death in low SDI group of nations [1]. In India, pneumonia was the fourth leading cause of mortality, for the year 2016 [2].

The data on healthcare-associated pneumonia (HCAP) from prospective studies are scant, notably from developing nations like India. Most of the data come from the studies done in Europe [3-6]. These studies did a comparative analysis of HCAP and community-acquired 
pneumonia (CAP) and concluded that microbial aetiology of HCAP was similar to CAP, but with higher morbidity and mortality in HCAP. The studies advocated that HCAP is an entity similar to CAP, despite higher morbidity and mortality. However, these studies excluded immunocompromised patients, and Vales et al. [4] even discussed pneumonia in immunocompromised patients as a separate entity. The immunocompromised state was described as Multidrug-resistant (MDR) risk factor in 2005 ATS/IDSA guidelines, the year in which HCAP was introduced as a new entity because of a large percentage of patients coming from the community were found to be infected with drug-resistant pathogens [7]. The exclusion of these patients can alter the results in studies aiming at determining the microbial etiological profile of HCAP and treatment outcomes in HCAP, as these patients also have a history of frequent hospitalisations and antibiotic use (prophylactic as well as therapeutic). Contrary to the European data, some of the US data suggest a higher prevalence of antibiotic resistance among the isolated organisms from these patients [8]. Against the backdrop of such a difference in the etiological profile between the United States and European data, it is essential to consider the data from developing countries, where pneumonia is more common than in developed nations. Also, the prevalence of MDR pathogens in pneumonia is higher, with alarming resistance to cephalosporins and carbapenems, especially among the isolates of Acinetobacter species, Klebsiella pneumoniae [9].

With hospital-acquired pneumonia (HAP), there is a consensus that Gram-negative bacteria predominate as etiological agents. In the United States, Acinetobacter species were the only Gram-negative bacteria that increased significantly as a cause of pneumonia in Intensive Care Units (ICUs) between 1986 and 2003 [10].

The alarming incidence of antibiotic resistance among hospitalised patients, in general, is increasing worldwide, including the USA, [11] European nations, Greece, [12] and India [9]. Reports of infections caused by organisms that are resistant to all currently available antibiotics, including Colistin, [13] are of most significant concern.

There is a scarcity of data on comparative profiling of HCAP and HAP from developing nations like India. With only $36 \%$ of the population using improved sanitation, [14] and high antibiotic consumption (Carbapenems in particular), [15] the problem of antibiotic resistance is severe in the Indian setting. A study on etiological profile of CAP at our centre $(n=225)$, found Streptococcus pneumoniae (30.5\%) and Legionella pneumoniae (17.5\%) to be the commonest agents, with in-hospital mortality of $8 \%$ [16]. We set out to determine the clinical spectrum, etiological profile and treatment outcomes of HCAP and HAP, in our setting and also assess if HCAP should be considered as an entity distinct from HAP in our setting.

\section{Methods}

\section{Setting}

A prospective study was conducted at the 800 -bedded tertiary care hospital, after getting approval from Sher-IKashmir Institute of Medical Sciences - Institutional ethics committee.

\section{Design}

The study design, along with HCAP and MDR risk factors, is illustrated in Fig. 1. The 2005 American Thoracic Society/ Infectious Disease Society of America (ATS/IDSA) criteria for clinically defined pneumonia were used to define HCAP, HAP and VAP [7]. Of the total of 554 cases of pneumonia seen over the study period, a total of 318 patients meeting the criteria (excluding CAP, $n=225$ ) were grouped in HCAP $(n=165,52 \%)$ and HAP $(n=153,48 \%)$ including VAP ( $n=63,20 \%$ ). Immunocompromised patients, an important risk factor for MDR pathogens, were also included to cover all the pneumonia groups for MDR pathogens. (Fig. 1) From HCAP, 11 immunocompromised cases were excluded. Data were collected on demographic features, patient characteristics including data on comorbidities, Charlson comorbidity index (CCI), [17] microbiological patterns of isolated organisms, radiological findings and clinical outcomes including in-hospital mortality and the length of hospital stay (LOS). Treatment of the patients was carried out employing standard hospital protocols based on the hospital ecology of microbiologic data.

\section{Microbiological Investigation}

Sputum and Endotracheal aspirate (ETA) cultures were done using blood agar, MacConkey agar and chocolate agar. BacT/ALERT ${ }^{\circledR}$ 3D automated system was used for blood cultures. Standard care was taken while processing sputum samples. Sputum was considered microbiologically adequate only if it contained $>10$ white blood cells for each epithelial cell at a magnification of $400 \times$ [18]. The purulent ETA secretions were defined as lower respiratory tract samples that contained $\geq 25$ neutrophils and $\leq 10$ squamous epithelial cells per lower power field $100 \times$. The threshold values of $10^{5}$ $\mathrm{CFU} / \mathrm{mL}$, for ETA, $10^{6}$ for sputum and $10^{3}$ for pleural fluid (obtained during thoracentesis and not from chest tubes) cultures were taken, and values below the threshold were considered as colonisers [19, 20]. Antibiotic susceptibility testing for isolates from sputum and ETA was done by Kirby 


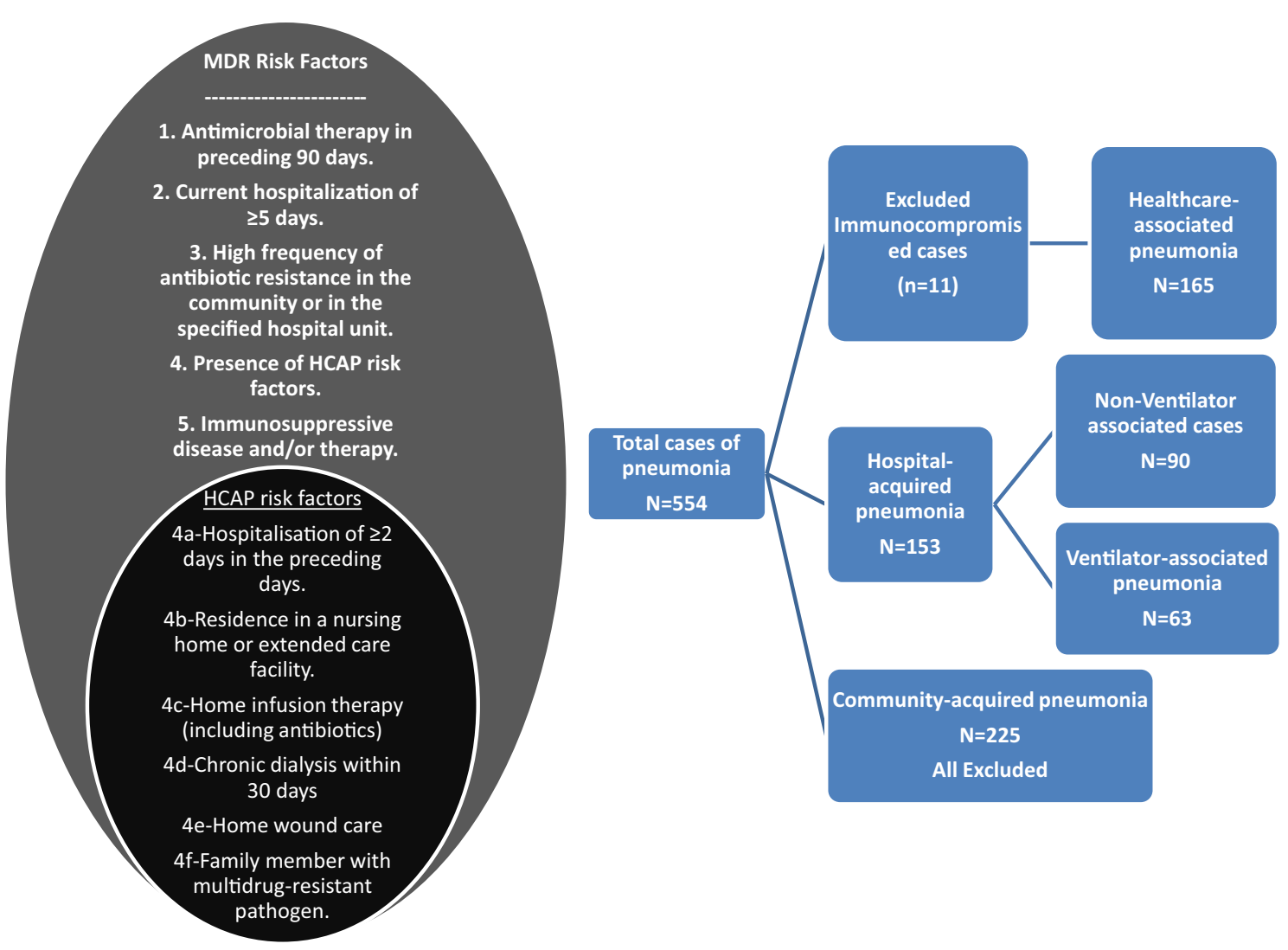

Fig. 1 Risk factors for multidrug-resistant pathogens causing pneumonia, and the study design

and Bauer disc diffusion method as per Clinical Laboratory Standard Institute (CLSI) guidelines. Antibiotic susceptibility testing for isolates from blood was done on VITEK® 2. The European Centre for Disease Control (ECDC) definitions for defining multi-, extensively , and pandrug-resistant (MDR, XDR, PDR) strains were used as follows [21]:

MDR strain: non-susceptible to $\geq 1$ agent in $\geq 3$ antimicrobial categories,

XDR strain: non-susceptible to $\geq 1$ agent in all but 2 or fewer antimicrobial categories,

PDR strain: non-susceptible to all antimicrobial agents listed, for specific organisms.

\section{Statistical Analysis}

Standard statistical methods as appropriate were employed. A multivariate regression analysis was performed to identify factors associated with antibiotic-resistant strains and inhospital mortality. First, univariate relationships were analysed to determine the possible factors related to the treatment outcome. Cox regression analysis was used to calculate the hazard ratio. Data were analysed using $95 \%$ confidence interval (CI) for estimates. SPSS software for Windows, version 21.0, was used (IBM-SPSS, Chicago, IL, USA).

\section{Results}

\section{Patient Characteristics}

Baseline demographic features and clinical characteristics are depicted in Tables 1 and 2, respectively. The age and CCI score of patients in HCAP were more, with higher mean and median values than in HAP $(p=0.00)$. In HCAP group, $94 \%$ of cases had received antibiotics before the current admission $(p=0.00)$. Among the risk factors for antibioticresistant pathogens, length of stay (LOS) $\geq 5$ days was seen in 68 cases of HCAP, and 81 cases of HAP $(p=0.036)$. The mean APACHE II scores were lesser in HCAP compared to HAP group $(F=6.295, p=0.013)$.

\section{Culture Results}

The microbiological profile of the patients is depicted in Table 3. Escherichia coli $(n=30,18 \%)$ and Acinetobacter baumannii $(n=62,41 \%)$ were the most common 
Table 1 Patient characteristics

\begin{tabular}{|c|c|c|c|}
\hline Variables & $\begin{array}{l}\text { HCAP } \\
(n=165)\end{array}$ & $\begin{array}{l}\text { HAP } \\
(n=153)\end{array}$ & $p$ value \\
\hline \multicolumn{4}{|l|}{ Age (years) } \\
\hline Mean \pm SD & $55.45 \pm 18.5$ & $45.15 \pm 20.6$ & 0.000 \\
\hline Median & 60 & 45 & 0.000 \\
\hline Range (years) & $16-90$ & $16-85$ & 0.000 \\
\hline Age $\geq 60$ years & $88(53.3 \%)$ & $59(38.6 \%)$ & 0.010 \\
\hline Age $<60$ years & $77(46.7 \%)$ & $94(61.4 \%)$ & 0.010 \\
\hline \multicolumn{4}{|l|}{ Gender } \\
\hline Male & $97(58.8 \%)$ & $92(60.1 \%)$ & 0.807 \\
\hline \multicolumn{4}{|l|}{ Comorbidities } \\
\hline $\operatorname{COPD}(n=45)$ & $31(18.8 \%)$ & $14(9.2 \%)$ & 0.014 \\
\hline $\operatorname{ILD}(n=7)$ & $7(4.2 \%)$ & $0(0.0 \%)$ & - \\
\hline Asthma $(n=2)$ & $1(0.6 \%)$ & $1(0.7 \%)$ & - \\
\hline Bronchiectasis $(n=5)$ & $4(2.4 \%)$ & $1(0.7 \%)$ & 0.205 \\
\hline Chronic lung disease $(n=61)$ & $46(27.9 \%)$ & $15(9.8 \%)$ & 0.000 \\
\hline Hypertension $(n=186)$ & $115(69.7 \%)$ & $71(46.4 \%)$ & 0.000 \\
\hline Diabetes $(n=36)$ & $25(15.2 \%)$ & $11(7.2 \%)$ & 0.025 \\
\hline $\mathrm{CAD}(n=24)$ & $11(6.7 \%)$ & $13(8.5 \%)$ & 0.537 \\
\hline CKD $(n=36)$ & $31(18.8 \%)$ & $5(3.3 \%)$ & 0.000 \\
\hline Neurological $(n=62)$ & $28(17.0 \%)$ & $34(22.2 \%)$ & 0.237 \\
\hline Malignancy $(n=39)$ & $26(15.8 \%)$ & $13(8.5 \%)$ & 0.049 \\
\hline \multicolumn{4}{|l|}{ Smoking } \\
\hline Never & $71(43.0 \%)$ & $89(58.2 \%)$ & 0.026 \\
\hline Ever smoker & $94(57.0 \%)$ & $74(48.4 \%)$ & \\
\hline \multicolumn{4}{|l|}{ Surgical intervention } \\
\hline Emergency surgery $(n=22)$ & $2(1.2 \%)$ & $20(13.1 \%)$ & - \\
\hline Elective surgery $(n=9)$ & $0(0.0 \%)$ & $9(6 \%)$ & \\
\hline Trauma $+\operatorname{burns}(n=17)$ & $2(1.2 \%)$ & $15(9.8 \%)$ & 0.004 \\
\hline \multicolumn{4}{|l|}{ MDR risk factors } \\
\hline Chemotherapy $(n=36)$ & $23(13.9 \%)$ & $13(8.5 \%)$ & 0.126 \\
\hline Steroids—systemic $(n=12)$ & $9(5.5 \%)$ & $3(2.0 \%)$ & 0.102 \\
\hline Steroids-inhaled $(n=23)$ & $18(10.9 \%)$ & $5(3.3 \%)$ & 0.009 \\
\hline Immunosuppressant $(n=39)$ & $28(17.0 \%)$ & $11(7.2 \%)$ & 0.008 \\
\hline Hemodialysis $\leq 30$ days $(n=33)$ & $30(18.2 \%)$ & $3(2.0 \%)$ & 0.000 \\
\hline Hospitalisation of $>2$ days in last 30 days $(n=148)$ & $145(87.9 \%)$ & $3(2.0 \%)$ & 0.000 \\
\hline Antibiotic use prior to hospitalisation $(n=159)$ & $155(93.9 \%)$ & $4(2.6 \%)$ & 0.000 \\
\hline Wound care $(n=14)$ & $9(5.5 \%)$ & $5(3.3 \%)$ & 0.342 \\
\hline \multicolumn{4}{|l|}{ Charlson comorbidity index } \\
\hline Mean \pm SD & $4.04 \pm 2.463$ & $2.44 \pm 2.539$ & 0.000 \\
\hline Range & $0-12$ & $0-9$ & 0.000 \\
\hline Median & 4 & 2 & 0.000 \\
\hline Score $>3$ & $101(61.2 \%)$ & $53(34.6 \%)$ & 0.000 \\
\hline
\end{tabular}

$H C A P$ healthcare-associated pneumonia, $H A P$ hospital-acquired pneumonia, $S D$ standard deviation, $C O P D$ chronic obstructive pulmonary diseases, $I L D$ interstitial lung diseases, $C A D$ coronary artery disease, $C K D$ chronic kidney disease, $M D R$ multidrug-resistant

microorganisms isolated in HCAP and HAP groups, respectively. Bacteria belonging to Enterobacteriaceae family were more frequently isolated in $\operatorname{HCAP}(n=49,30 \%)$ than in HAP group $(n=40,26 \%)$. Details of culture methods used and organisms isolated are given in Table S1. ESKAPE group of bacteria were isolated in 94 cases (104 isolates) in HCAP and 104 cases (144 isolates) in HAP group $(p=0.001)$. Among patients with chronic lung conditions $(n=61), A$. baumannii $(n=13, \mathrm{HCAP}=7, \mathrm{HAP}=6, p=0.067)$ and $E$. $\operatorname{coli}(n=12,22 \%$, HCAP-10, HAP- $2, p=0.712)$ were the 
Table 2 Patient clinical characteristics and disease severity

\begin{tabular}{llll}
\hline Variable & $\begin{array}{l}\text { HCAP } \\
(n=165)\end{array}$ & $\begin{array}{l}\text { HAP } \\
(n=153)\end{array}$ & $p$ value \\
\hline APACHE II score $(\geq 17)(n=165)$ & $82(49.7 \%)$ & $83(54 \%)$ & 0.000 \\
Mean APACHE II score \pm SD & $17.55 \pm 6.406$ & $19.74 \pm 8.843$ & 0.013 \\
& $95 \%$ CI $16.57-18.54$ & $95 \%$ CI $18.33-21.15$ & \\
APACHE II score—range & $7-37$ & $7-44$ & 0.013 \\
Acute kidney injury $(n=151)$ & $73(44.24 \%)$ & $78(51 \%)$ & 0.208 \\
Coagulopathy $(n=98)$ & $45(27 \%)$ & $53(34.6 \%)$ & 0.155 \\
Septic shock $(n=174)$ & $77(46.7 \%)$ & $97(63.3 \%)$ & 0.002 \\
Encephalopathy $(n=150)$ & $64(38.8 \%)$ & $86(56.2 \%)$ & 0.002 \\
Congestive cardiac failure $(\mathrm{CCF})(n=31)$ & $23(14 \%)$ & $8(5.2 \%)$ & 0.009 \\
Pleural effusion $(n=95)$ & $57(34.5 \%)$ & $38(24.8 \%)$ & 0.059 \\
Empyema $(n=19)$ & $14(8.5 \%)$ & $5(3.3 \%)$ & 0.050 \\
Multilobar consolidation $(n=106)$ & $43(26.1 \%)$ & $63(41.2 \%)$ & 0.004 \\
\hline
\end{tabular}

HCAP healthcare-associated pneumonia, HAP hospital-acquired pneumonia, $S D$ standard deviation, APACHE II acute physiology and chronic health evaluation-II

Table 3 Culture results in HCAP and HAP

\begin{tabular}{|c|c|c|c|c|c|c|c|}
\hline Etiological agent & $\operatorname{HCAP}(n=165)$ & $\begin{array}{l}\text { HAP + VAP } \\
(n=153)\end{array}$ & $p$ value & Etiological agent & $\operatorname{HCAP}(n=165)$ & $\mathrm{HAP}+\mathrm{VAP}(n=153)$ & $p$ value \\
\hline Escherichia coli & $30(18 \%)$ & $17(11 \%)$ & 0.083 & Proteus mirabilis & 0 & $1(0.7 \%)$ & \\
\hline $\begin{array}{l}\text { Acinetobacter bauman- } \\
\text { nii }\end{array}$ & $23(14 \%)$ & $62(41 \%)$ & 0.000 & $\begin{array}{l}\text { Mycobacterium tuber- } \\
\text { culosis }\end{array}$ & $3(1.8 \%)$ & 0 & 0.100 \\
\hline Klebsiella pneumoniae & $18(11 \%)$ & $16(10 \%)$ & 1.000 & Serratia marcescens & 0 & $2(1.3 \%)$ & 0.100 \\
\hline $\begin{array}{l}\text { Pseudomonas aerugi- } \\
\text { nosa }\end{array}$ & $11(7 \%)$ & $21(14 \%)$ & 0.012 & Serratia liquefaciens & 0 & $1(0.7 \%)$ & \\
\hline $\begin{array}{l}\text { Pseudomonas fluore- } \\
\text { scens }\end{array}$ & 0 & $1(0.7 \%)$ & & Alcaligenes faecalis & 0 & $2(1.3 \%)$ & 0.250 \\
\hline Pseudomonas putida & 0 & $1(0.7 \%)$ & & Aerococcus viridans & $1(0.6 \%)$ & $1(0.7 \%)$ & 0.975 \\
\hline Pseudomonas stutzeri & 0 & $1(0.7 \%)$ & & $\begin{array}{l}\text { Stenotrophomonas } \\
\text { maltophilia }\end{array}$ & 0 & $2(1.3 \%)$ & 0.250 \\
\hline Enterococcus faecium & $8(4.8 \%)$ & $7(4.6 \%)$ & 0.750 & Listeria monocytogenes & $1(0.6 \%)$ & $1(0.7 \%)$ & 0.975 \\
\hline Enterococcus faecalis & 0 & $2(1.3 \%)$ & & $\begin{array}{l}\text { Achromobacter denitri- } \\
\text { ficans }\end{array}$ & 0 & $1(0.7 \%)$ & 0.500 \\
\hline Staphylococcus aureus & $7(4.2 \%)$ & $5(3.3 \%)$ & 0.772 & $\begin{array}{l}\text { Chryseobacterium } \\
\text { indologenes }\end{array}$ & 0 & $1(0.7 \%)$ & 0.500 \\
\hline $\begin{array}{l}\text { Staphylococcus hominis } \\
\quad(\text { MRSH })\end{array}$ & $5(3 \%)$ & $7(4.6 \%)$ & 0.500 & Kluyvera cryocrescens & 0 & $1(0.7 \%)$ & 0.500 \\
\hline Enterobacter cloacae & $2(1.2 \%)$ & $3(2 \%)$ & 0.750 & $\begin{array}{l}\text { Leuconostoc mesenter- } \\
\text { oides }\end{array}$ & 0 & $1(0.7 \%)$ & 0.500 \\
\hline Burkholderia cepacia & $3(1.8 \%)$ & $2(1.3 \%)$ & 0.750 & Moraxella catarrhalis & 0 & $1(0.7 \%)$ & 0.500 \\
\hline $\begin{array}{l}\text { Sphingomonas pauci- } \\
\text { mobilis }\end{array}$ & $1(0.6 \%)$ & $3(2 \%)$ & 0.500 & Providencia stuartii & 0 & $1(0.7 \%)$ & 0.500 \\
\hline Citrobacter freundii & $1(0.6 \%)$ & $2(1.3 \%)$ & 0.750 & Sterile & $64(38.8 \%)$ & $32(21 \%)$ & 0.001 \\
\hline Proteus vulgaris & $1(0.6 \%)$ & $2(1.3 \%)$ & 0.500 & Polymicrobial & $13(8 \%)$ & $39(25.5 \%)$ & 0.010 \\
\hline
\end{tabular}

Bold values indicate the most commonly isolated bacteria in each group

HCAP healthcare-associated pneumonia, HAP hospital-acquired pneumonia, MRSH methicillin-Resistant Staphylococcus hominis

most commonly isolated microorganisms. A total of 13 cases in HCAP and 39 cases in HAP had a polymicrobial aetiology $(p=0.00)$, out of which 5 cases in HCAP and 4 cases in HAP group had a chronic lung condition $(p=0.204)$. 


\section{Antibiotic Resistance}

From 87 (53\%) cases in HCAP group and 134 (87\%) cases in HAP group, antibiotic-resistant bacteria were isolated. In HAP group, three PDR bacteria were isolated. In HCAP, among patients who had received antibiotics before hospitalisation, MDR and XDR bacteria were isolated from $21 \%$ and $32 \%$ of cases, respectively. $(p=0.349)$. Multidrugresistant bacteria were isolated more among patients with $\operatorname{HCAP}(p=0.495)$, only because the incidence of extensively drug-resistant bacteria was markedly high in $\operatorname{HAP}(p=0.00)$. The antibiotic susceptibility of the most common bacteria is shown in e-Table 2. Vancomycin-resistant Enterococcus (VRE) was isolated from $2(1 \%)$ cases in HCAP and 4 (3\%) cases in HAP. Also, Methicillin-Resistant Staphylococcus aureus was seen in 4 (2\%) cases in HCAP and 5 (3\%) cases in HAP group. All Methicillin Sensitive Staphylococcus aureus (MSSA), 3 (1.8\%) were isolated from HCAP. In this study, among all 318 cases, out of total 476 isolates and from 254 positive cultures, $91(40 \%)$ isolates in HCAP and $145(59 \%)$ in HAP $(p=0.000)$ isolates were resistant to at least one category of antibiotics used in the empirical antibiotic regimen [7]. (Table S2) Details of MDR and XDR isolates are shown in Table 4. Using multivariate regression analysis, chronic lung diseases were the strongest predictor of $M D R$ bacteria (OR 2.73, 95\% CI 1.26-5.915, $p=0.011$ ). Isolation of $A$. baumannii (OR $35.503,95 \% \mathrm{CI}$ 14.688-85.817, $p=0.000$ ), Pseudomonas spp. (OR 8.913, 95\% CI 2.762-28.76, $p=0.000)$ and bacteria belonging to the Enterobacteriaceae family collectively (OR 9.533, 95\% CI 2.62-34.688, $p=0.001$ ) along with immunocompromised state (OR 4.050, 95\% CI 1.39-11.796, $p=0.010$ ) were the strongest predictors for XDR pathogens. The probability of isolating bacteria sensitive only to Polymyxin/Colistin ( $n=70$ (22\%); HCAP-22, HAP-48) was strongly associated with isolation of A. baumannii (OR 8.386, 95\% CI $3.698-19.015, p=0.000$ ) and Pseudomonas spp. (OR 6.063, 95\% CI 1.965-18.705, $p=0.002$ ).

Table 4 Distribution of drug-resistant isolates among HCAP and HAP groups

\begin{tabular}{|c|c|c|c|c|c|c|}
\hline Isolate & & Pneumonia & $\operatorname{MDR}(n)$ & $\operatorname{XDR}(n)$ & $\operatorname{PDR}(n)$ & $\begin{array}{l}\text { Sensitive only to } \\
\text { colistin/polymyxin } \\
\text { (n) }\end{array}$ \\
\hline \multirow[t]{2}{*}{ Number of cases (number of isolates) } & & HCAP & $38(40)$ & $49(54)$ & $0(0)$ & $22(22)$ \\
\hline & & HAP & $30(33)$ & $84(110)$ & $3(3)$ & $48(53)$ \\
\hline \multirow[t]{2}{*}{ Acinetobacter baumannii $(n)$} & & HCAP & 4 & 16 & 0 & 10 \\
\hline & & HAP & 7 & 60 & 0 & 33 \\
\hline \multirow[t]{2}{*}{ Escherichia coli $(n)$} & & HCAP & 13 & 13 & 0 & 3 \\
\hline & & HAP & 7 & 7 & 0 & 3 \\
\hline \multirow[t]{2}{*}{ Pseudomonas spp. (n) } & & HCAP & 5 & 6 & 0 & 2 \\
\hline & & HAP & 1 & 20 & 1 & 13 \\
\hline \multirow[t]{2}{*}{ Klebsiella pneumoniae $(n)$} & & HCAP & 2 & 12 & 0 & 6 \\
\hline & & HAP & 2 & 13 & 0 & 7 \\
\hline \multirow[t]{2}{*}{ Staphylococcus aureus ( $n$ ) } & & HCAP & 4 & 0 & 0 & - \\
\hline & & HAP & 4 & 1 & 0 & - \\
\hline \multirow[t]{2}{*}{ Others $(n)$} & & HCAP & 12 & 8 & 0 & 1 \\
\hline & & HAP & 12 & 16 & 2 & 4 \\
\hline \multirow[t]{2}{*}{ Death [number of cases (number of isolates)] } & & HCAP & $15(17)$ & $12(13)$ & 0 & $5(5)$ \\
\hline & & HAP & $13(14)$ & $38(53)$ & $1(1)$ & $26(29)$ \\
\hline \multirow[t]{2}{*}{ XDR } & HCAP & \multicolumn{5}{|c|}{$\begin{array}{l}\text { Citrobacter freundii-1, Enterobacter cloacae-2, Enterococcus faecium-4, } \\
\text { Burkholderia cepacia -1 }\end{array}$} \\
\hline & HAP & \multicolumn{5}{|c|}{$\begin{array}{l}\text { Alcaligenes faecalis-2, Citrobacter freundii-1, Enterobacter cloacae-2, } \\
\text { Enterococcus faecium -5, Burkholderia cepacia-1, Proteus vulgaris-1, } \\
\text { Sphingomonas paucimobilis-2, MRSH-1, Chryseobacterium indolo- } \\
\text { genes-1 }\end{array}$} \\
\hline \multirow[t]{2}{*}{ MDR } & HCAP & \multicolumn{5}{|c|}{$\begin{array}{l}\text { Citrobacter freundii-1, Enterococcus faecium-4, MRSH-4, Burkholderia } \\
\text { cepacia-2, Sphingomonas paucimobilis -1 }\end{array}$} \\
\hline & HAP & \multicolumn{5}{|c|}{$\begin{array}{l}\text { Providencia stuartii-1, Achromobacter denitrificans-1, Enterococcus } \\
\text { faecium-2, Leuconostoc mesenteroides - 1, MRSH-4, Kluyvera cryocres- } \\
\text { cens-1, Burkholderia cepacia-1, Proteus vulgaris -1 }\end{array}$} \\
\hline
\end{tabular}


Fig. 2 Outcomes and complications of HCAP and HAP groups, with comparison of main complications in all three categories-HCAP, non-ventilator-associated HAP (nvHAP) and VAP separately

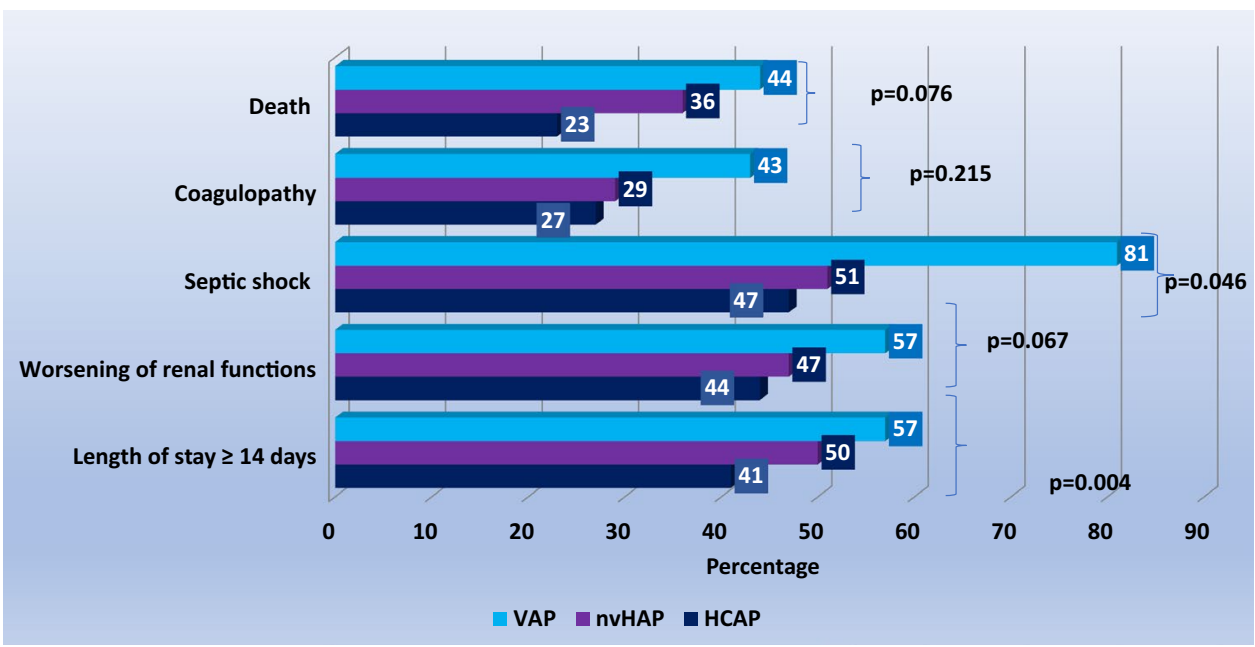

\section{Clinical Outcomes}

The overall incidence of in-hospital mortality, acute kidney injury/worsening of renal functions, coagulopathy, septic shock and encephalopathy was higher in HAP group. The other complications like the congestive cardiac failure (CCF), pleural effusion and empyema were higher in HCAP group. When clinical outcomes were compared between HCAP and non-ventilator-associated HAP, septic shock, coagulopathy, worsening of renal functions (Fig. 2) were comparable, but still more severe in non-ventilatorassociated HAP. The LOS $\geq 5$ days was more among in HAP group, with mean $\pm \mathrm{SD}=17.85 \pm 12.212$ (range $2-85$ days), compared to mean $\pm \mathrm{SD}=14.23 \pm 10.158$ (range 1-61 days) in HCAP group. The Levene's test for equality of variance for LOS value was found significant $(F=4.341, p=0.038)$, and non-parametric test (Mann-Whitney test) was applied for the lack of homogeneity (Overall Mean $\pm \mathrm{SD}=15.97 \pm 11.321$, Mean rank: HCAP $=144.99$, HAP $=175.15)$. The length of stay in HAP group was more than that of HCAP group, and the relation was statistically significant $(p=0.003)$. There were 98 deaths during the study [HCAP: 38 (23\%); HAP: $60(39 \%)$ including VAP: $28(44 \%) ; p=0.002]$. Comparison of various parameters to in-hospital mortality is depicted in Table 5. The ESKAPE group (Enterococcus faecium, Staphylococcus aureus, K. pneumoniae, A. baumannii, Pseudomonas aeruginosa, Enterobacter species and E. coli) [22] of bacteria were responsible for more deaths in $\operatorname{HAP}(p=0.005)$.

Using multivariate regression analysis, various factors were analysed for predictability of in-hospital mortality. (Table S3) In HCAP and HAP group, APACHE II score $\geq 17$ and septic shock were the most reliable predictors of inhospital mortality. (Table 5) In addition to these factors, the presence of consolidation was also a strong predictor of mortality in HCAP, but not in HAP. (Table S3) Various factors were analysed, using Cox Regression analysis for inhospital mortality as an outcome. It was found that APACHE II score (HR 6.439, 95\% CI 3.591-11.549, $p=0.000$ ), septic shock $(3.229,95 \%$ CI $1.931-5.4, p=0.000)$, and CCI score $>3$ (HR 1.576, 95\% CI 1.051-2.364, $p=0.028$ ) were the significant causes of in-hospital mortality in our study population. Comparison of both groups is given in Table 5 .

\section{Discussion}

Our data reflect the problem of antibiotic resistance, and adverse treatment outcomes in HCAP are as severe as in HAP in our setting, contrary to the European data [3-6]. To the best of our knowledge, this is the first prospective study of its kind where HCAP and HAP were studied, and results analysed, notably from India. We found an alarming incidence of MDR and XDR bacteria in both groups. The status of HCAP is still uncertain after its removal from HAP, [23] and treating HCAP as a separate entity needs to be addressed, also considering data from developing nations. CAP and HAP lie on two extremes of the pneumonia spectrum, and HCAP is in the grey area where some of the recent studies have advocated keeping HCAP in the CAP group [3-6]. The grounds for the debate over HCAP status have been the rising concerns regarding resistance to antibiotics including antibiotics used in empirical antibiotic regimens recommended [7]. There is a consensus among various studies, over higher morbidity or mortality in HCAP [3-6, 8]. Although the higher mortality and morbidity in HCAP needs to be addressed separately, the controversy in HCAP is somewhat over microbiological aetiology, $[3-6,8]$ and the spectrum of antibiotic resistance (non-MDR [3-6] vs MDR [8]). 
Table 5 In-hospital mortality: comparison of microbiological and clinical parameters

\begin{tabular}{|c|c|c|c|}
\hline $\begin{array}{l}\text { Variable } \\
\text { Total deaths }=98\end{array}$ & $\begin{array}{l}\operatorname{HCAP}(n) \\
n=38\end{array}$ & $\begin{array}{l}\operatorname{HAP}(n) \\
n=60\end{array}$ & $p$ value \\
\hline \multicolumn{4}{|l|}{ Microbiological parameters } \\
\hline MDR bacteria $(n=28,28.6 \%)$ & 15 & 13 & NS \\
\hline XDR bacteria $(n=49,50 \%)$ & 11 & 38 & 0.009 \\
\hline Bacteria sensitive only to polymyxin $(n=31,44 \%)$ & 5 & 26 & 0.002 \\
\hline $\operatorname{ESKAPE}(n=71,72 \%)$ & 24 & 47 & 0.005 \\
\hline Positive bacterial culture $(n=77,78.5 \%)$ & 26 & 51 & 0.011 \\
\hline \multicolumn{4}{|l|}{ Clinical parameters } \\
\hline APACHE II score $\geq 17(n=85,87 \%)$ & 34 & 51 & 0.000 \\
\hline Multivariate regression analysis. OR;95\% CI & $13.99 ; 4.674-47.874$ & $10.802 ; 4.721-24.717$ & 0.000 \\
\hline Cox regression analysis. HR; 95\% CI & $6.088 ; 3.381-10.963$ & $6.454 ; 3.595-11.585$ & 0.000 \\
\hline Septic shock $(n=80,82 \%)$ & 28 & 52 & 0.000 \\
\hline Multivariate regression analysis. OR; 95\% CI & $4.457 ; 1.992-9.975$ & $6.933 ; 2.969-16.192$ & 0.000 \\
\hline Cox regression. HR; 95\% CI & $3.140 ; 1.866-5.285$ & $3.274 ; 1.956-5.481$ & 0.000 \\
\hline Charlson comorbidity index $(\mathrm{CCI})$ score $>3(n=48,49 \%)$ & 25 & 23 & 0.027 \\
\hline Multivariate regression analysis. OR; 95\% CI & $\begin{array}{l}2.318 ; 1.394-3.854 \\
p=0.001\end{array}$ & $\begin{array}{l}0.738 ; 0.440-1.239 \\
p=0.251\end{array}$ & - \\
\hline Cox regression. HR; 95\% CI & $\begin{array}{l}1.796 ; 1.175-2.745 \\
p=0.007\end{array}$ & $1.629 ; 1.081-2.456, p=0.020$ & - \\
\hline Length of stay (LOS) $\geq 5$ Days $(n=71,72 \%)$ & 25 & 46 & 0.202 \\
\hline Multivariate regression analysis. OR; 95\% CI & $\begin{array}{l}2.221 ; 1.360-3.627 \\
p=0.001\end{array}$ & $0.725 ; 0.431-1.220, p=0.226$ & - \\
\hline Cox regression. HR; 95\% CI & $0.258 ; 0154-0.433$ & $0.257 ; 0.153-0.432$ & 0.000 \\
\hline
\end{tabular}

$H C A P$ healthcare-associated pneumonia, $H A P$ hospital-acquired pneumonia, $M D R$ multidrug-resistant, XDR extensively drug resistant, ESKAPE Enterococcus faecium, Staphylococcus aureus, Klebsiella pneumoniae, Acinetobacter baumannii, Pseudomonas aeruginosa, Enterobacter species and E. coli [19], OR odd's ratio, $H R$ hazard ratio; APACHE II acute physiology and chronic health evaluation-II, $C I$ confidence interval

The most frequent cause of HCAP varies with S. pneumoniae in Spain, [3-5] Iceland [6] and UK, [24] and as per some studies from the USA-Staphylococcus aureus (47\%) and $P$. aeruginosa $(25 \%)[8,25]$. The other question to be addressed is, which antibiotics can be used in empirical management [7] of HCAP, which as per the European studies has non-MDR aetiology [3-6]. A study from the USA showed a higher incidence of antibiotic-resistant pathogens [8]. In our study, we found an alarming rate of Carbapenemresistant Enterobacteriaceae (CDC-urgent threat) [26] and XDR Acinetobacter, and Pseudomonas species (CDC-Serious threat) [26]. The data from 50 nations reported the $P$. aeruginosa as the most frequent pathogen, followed by $A$. baumannii, with resistance percentage of $40 \%$ and $90 \%$ [27]. In our study, bacteria sensitive only to Polymyxin/Colistin were isolated from a large number of cases-more frequently in HAP, but also in HCAP. ESKAPE bacteria in our study were associated with poorer clinical outcomes and increased mortality. Since ESKAPE bacteria are commonly isolated from HCAP and HAP, the group can be targeted in empirical antibiotic treatment. As far as bacteriology is considered, our study shows a higher incidence of antibiotic resistance in HCAP $(n=83)$ and HAP $(n=95)$, differing mainly in the severity of resistance. Also, the debate on initial empirical treatment [7] has another aspect to it. Most of the isolates in our studies were resistant to antibiotics used in empirical treatment, which could have influenced the high mortality in our study population. The high microbiological yield in our study population (70\%) (HCAP-61\%, HAP-79\%) is another perilous factor, which is more than the overall rate of pathogen detection among patients with CAP (30-40\%) [28].

The mortality in our study was high, with $23 \%$ mortality in HCAP group, which was in consonance with other previous studies, where it ranged from 10 to $24.4 \%$ [3-6, 8, 24, 29-32]. In our study, the mortality rate of $39 \%$ was seen in HAP group and was also in consonance with other previous studies, where the mortality rates ranged from 9 to $43.5 \%$ $[8,29,30,32]$.

The growing medical tourism industry [33] and the risk of acquisition of MDR strains among travellers [34] make our findings more relevant. The spread of New Delhi Metallo- $\beta$-lactamases which was mostly found among E. coli and Klebsiella pneumonia is a notable example [35]. In a study from our centre, out of 100 Imipenemresistant isolates, $55 \%$ were Carbapenemase positive, and of the 15 class B Metallo-beta-lactamase producers, nine 
carried the bla(NDM1) gene. The gene was isolated not only from K. pneumoniae but also from A. baumannii, $P$. aeruginosa, Citrobacter freundii and E. coli [36]. The emergence of plasmid-mediated Colistin resistance mechanism (MCR-1) in animals and humans has already indicated that bacteria are becoming resistant to even the last resort antibiotic-the Colistin [37]. In a recently published study, from the USA, $32 \%$ of $P$. aeruginosa isolates were MDR, even in cases of CAP [38].

Limitations: This is a single-centre based study. In the state of Jammu and Kashmir, SKIMS is an apex tertiary care hospital offering advanced healthcare with proper laboratory support and gets referrals from other hospitals and parts of the state. Also, we did not test for viruses and atypical pathogens, which may have further decreased the number of cases with no microbial aetiology. Candida species were isolated from 9 cases, but were not included in final analysis, as per the guidelines [19]. None were isolated from pleural fluid and no biopsies were performed. Out of 9, two were isolated from sputum and one was isolated from ETA. No BAL or post-mortem histopathological biopsy was done to confirm our findings. The study excluded CAP, which has been studied separately at our centre $(n=225)$ [16].

\section{Conclusions}

HCAP needs to be categorised separately as a third category, if not in HAP spectrum, because the patient characteristics, bacterial etiological profiling, antibiotic susceptibility and outcomes are unique to HCAP, and can be better addressed when categorised separately. The high mortality in HCAP is multifactorial, clinical (increasing age, comorbidities, pneumonia severity and complications) and microbiological (the type of bacteria and antibiotic susceptibility) and use of empirical antibiotic therapy is justified, but emphasising the need of early aggressive approach and supportive care in HCAP can improve patient outcome.

\footnotetext{
Author Contributions SK-Study design, patient selection, sample collection, data collection, data entry and analysis, main manuscript writer, manuscript review, editing and main manuscript approval. RAJ-Concept, study design, patient selection, team leader, co-ordination between various teams and departments, manuscript review and main manuscript approval. BAF-Headed the microbiology team for blood and respiratory culture, culture result reporting and manuscript editing. RR-Microbiological aspects, culture results and marker collection. PK-Diagnosing pneumonia, radiological confirmation, patient selection in Department of Internal medicine and facilitating co-ordination with other departments. SS—Diagnosing pneumonia, radiological confirmation, patient selection. UHK-Patient selection and data collection. SMQ - patient selection and data collection. SRM-Data analysis and manuscript editing. SM-Data collection and data entry.
}

Funding The study was supported by the Institutional research grant provided by Sher-I-Kashmir Institute of Medical Sciences.

\section{Compliance with Ethical Standards}

Conflict of interest All the authors in study have nothing to disclose.

\section{References}

1. GBD 2016 Causes of Death Collaborators. Global, regional, and national age-sex specific mortality for 264 causes of death, 1980-2016: a systematic analysis for the Global Burden of Disease Study 2016. Lancet. 2017; 390(10100): 1151-1210

2. India State-level Disease Burden initiative Collaborators. Nations within a nation: variations in epidemiological transition across the states of India, 1990-2016 in the Global Burden of Disease Study. Lancet. 2017. 390(10111), 2437-2460

3. Polverino E, Torres A, Menendez R, Cilloniz C, Valles JM, Capelastegui A, Marcos MA, Alfageme I, Zalacain R, Almirall J, Molinos L, Bello S, Rodriguez F, Blanquer J, Dorado A, Llevat N, Rello J (2013) Microbial aetiology of healthcare associated pneumonia in Spain: a prospective, multicentre, casecontrol study. Thorax 68(11):1007-1014

4. Valles J, Martin-Loeches I, Torres A, Diaz E, Seijas I, Lopez MJ, Garro P, Castillo C, Garnacho-Montero J, Martin Mdel M, de la Torre MV, Olaechea P, Cilloniz C, Almirall J, Garcia F, Jimenez R, Seoane E, Soriano C, Mesalles E, Posada P (2014) Epidemiology, antibiotic therapy and clinical outcomes of healthcare-associated pneumonia in critically ill patients: a Spanish cohort study. Intensive Care Med 40(4):572-581

5. Carratala J, Mykietiuk A, Fernandez-Sabe N, Surarez C, Dorca J, Verdaguer R, Manresa F, Gudiol F (2007) Healthcare-associated pneumonia requiring hospital admission: epidemiology, antibiotic therapy, and clinical outcomes. Arch Intern Med 167(13):1393-1399

6. Bjarnason A, Asgeirsson $\mathrm{H}$, Baldursson $\mathrm{O}$, Kristinsson $\mathrm{KG}$, Gottfredsson M (2015) Mortality in healthcare-associated pneumonia in a low resistance setting: a prospective observational study. Infect Dis (Lond) 47(3):130-136

7. American Thoracic Society. Infectious Diseases Society of America: guidelines for the management of adults with Hospital-acquired pneumonia, Ventilator-associated, and Healthcareassociated pneumonia. Am J Respir Crit Care Med. 2005; 171 : 388-416

8. Kollef MH, Shorr A, Tabak YP, Gupta V, Liu LZ, Johannes RS (2005) Epidemiology and outcomes of healthcare-associated pneumonia: results from a large US database of culture-positive pneumonia. Chest 128(6):3854-3862

9. Mehta Y, Jaggi N, Rosenthal VD, Kavathekar M, Sakle A, Munshi N, Chakravarthy M, Todi SK, Saini N, Rodrigues C, Varma K, Dubey R, Kazi MM, Udwadia FE, Myatra SN, Shah S, Dwivedy A, Karlekar A, Singh S, Sen N, Limaye-Joshi K, Ramachandran B, Sahu S, Pandya N, Mathur P, Sahu S, Singh SP, Bilolikar AK, Kumar S, Mehta P, Padbidri V, Gita N, Patnaik SK, Francis T, Warrier AR, Muralidharan S, Nair PK, Subhedar VR, Gopinath R, Azim A, Sood S (2016) Deviceassociated infection rates in 20 cities of India, Data summary for 2004-2013: Findings of the International Nosocomial infection Control Consortium. Infect Control Hosp Epidemiol 37(2):172-181

10. Gaynes R, Edwards JR (2005) Overview of nosocomial infections caused by gram-negative bacilli. Clin Infect Dis 41:848-854 
11. Hidron AI, Edwards JR, Patel J, Horan TC, Sievert DM, Pollock DA, Fridkin SK, National Healthcare Safety Network team; Participating National Healthcare Safety Network Facilities (2008) NHSN annual update: antimicrobial-resistant pathogens associated with healthcare-associated infections: annual summary of data reported to the National Healthcare Safety Network at the Centers for Disease Control and Prevention, 2006-2007. Infect Control Hosp Epidemiol 29:996-1011 (Erratum, Infect Control Hosp Epidemiol 2009;30:107)

12. Souli M, Galani I, Giamarellou H (2008) Emergence of extensively drug-resistant and pandrug-resistant Gram-negative bacilli in Europe. Euro Surveill 13(47):19045

13. Valencia R, Arroyo LA, Conde M, Aldana JM, Torres MJ, Fernandez-Cuenca F, Garnacho-Montero J, Cisneros JM, Ortiz C, Pachon J, Aznar J (2009) Nosocomial outbreak of infection with pan-drug-resistant Acinetobacter baumannii in a tertiary care university hospital. Infect Control Hosp Epidemiol 30:257-263

14. World Health Organisation (2015) World health statistics 2015 (Internet). World Health Organisation, Geneva. http://apps.who. int/iris/bitstream/10665/170250/1/9789240694439_eng.pdf?ua=1

15. The Centre for Disease Dynamics, Economics \& Policy, Ramanan Laxminarayan (2015). Economics of antibiotic resistance; Zurich, Latsis Symposium, 2015 (Internet). http://www.cddep.org/sites/ default/files/zurich.jul_.2015.pdf. Accessed 24 Jul 2017

16. Para RA, Fomda BA, Jan RA, Shah S, Koul PA (2018) Microbial etiology in hospitalized North Indian adults with communityacquired pneumonia. Lung India 35(2):108-115

17. Charlson ME, Pompei P, Ales KL, MacKenzie CR (1987) A new method of classifying prognostic comorbidity in longitudinal studies: development and validation. J Chronic Dis 40(5):373-383

18. Musher DM, Montoya R, Wanahita A (2004) Diagnostic value of microscopic examination of Gram-stained sputum and sputum cultures in patients with bacteremic pneumococcal pneumonia. Clin Infect Dis 39(2):165-169

19. Magill SS, Klompas M, Balk R, Burns SM, Deutschman CS, Diekema D, Fridkin S, Greene L, Guh A, Gutterman D, Hammer B, Henderson D, Hess D, Hill NS, Horan T, Kollef M, Levy M, Septimus E, Vanantwerpen C, Wright D, Lipsett P (2013) Developing a new, national approach to surveillance for ventilator associated events: Executive summary. Clin Infect Dis 57(12):1742-1746

20. Joseph NM, Sistla S, Dutta TK, Badhe AS, Parija SC (2010) Ventilator-associated pneumonia: role of colonizers and value of routine endotracheal aspirate cultures. Int J Infect Dis 14:723-729

21. Magiorkas AP, Srinivasan A, Carey RB, Carmeli Y, Falagas ME, Giske CG, Harbath S, Hindler JF, Kahlmeter G, Olsson-Liljequist B, Paterson DL, Rice LB, Stelling J, Struelens MJ, Vatopoulos A, Weber JT, Monnet DL (2012 March) Multidrug-resistant, extensively drug-resistant and pandrug-resistant bacteria: an international expert proposal for interim standard definitions for acquired resistance. Clin Microbiol Infect 18(3):268-281

22. Rice LB (2010) Progress and challenges in implementing the research on ESKAPE pathogens. Infect Control Hosp Epidemiol 31(Suppl 1):S7-S10

23. Kalil AC, Metersky ML, Klompas M, Muscedere J, Sweeney DA, Palmer LB, Napolitano LM, O'Grady NP, Bartlett JG, Carratalà J, El Solh AA, Ewig S, Fey PD, File TM Jr, Restrepo MI, Roberts JA, Waterer GW, Cruse P, Knight SL, Brozek JL (2016) Management of adults with Hospital-acquired pneumonia and Ventilator associated pneumonia: 2016 Clinical practice guidelines by the Infectious disease society of America and American Thoracic Society. Clin Infect Dis 1;63(5):e61-e111

24. Chalmers JD, Taylor JK, Singanayagam A, Fleming GB, Akram AR, Mandal P, Choudhury P, Hill AT (2011) Epidemiology, antibiotic therapy, and clinical outcomes in healthcare-associated pneumonia: a UK cohort study. Clin Infect Dis 53(2):107-113
25. Micek ST, Kollef KE, Reichley RM, Roubinian N, Kollef MH (2007) Healthcare-associated pneumonia and communityacquired pneumonia: a single center experience. Antimicrob Agents Chemother 51(10):3568-3573

26. Center for disease Control and Prevention, National Center for Emerging and Zoonotic Diseases, and Division of Healthcare Quality Promotion (2017). Antibiotic resistance threats in United States 2013-CDC report. Last updated April 2017. https://www. cdc.gov/drugresistance/threat-report-2013/pdf/ar-threats-2013508.pdf. Accessed 24 July 2017

27. Rosenthal VD, Al-Abdely HM, El-Kholy AA, AlKhawaja SA, Leblebicioglu H, Mehta Y, Rai V, Hung NV, Kanj SS, Salama MF, Salgado-Yepez E, Elahi N, Morfin Otero R, Apisarnthanarak A, De Carvalho BM, Ider BE, Fisher D, Buenaflor MC, Petrov MM, Quesada-Mora AM, Zand F, Gurskis V, Anguseva T, Ikram A, Aguilar de Moros D, Duszynska W, Mejia N, Horhat FG, Belskiy V, Mioljevic V, Di Silvestre G, Furova K, Ramos-Ortiz GY, Gamar Elanbya MO, Satari HI, Gupta U, Dendane T, Raka L, Guanche-Garcell H, Hu B, Padgett D, Jayatilleke K, Ben Jaballah N, Apostolopoulou E, Prudencio Leon WE, Sepulveda-Chavez A, Telechea HM, Trotter A, Alvarez-Moreno C, Kushner-Davalos L (2016) International Nosocomial Infection Control Consortium report, data summary of 50 countries for 2010-2015: deviceassociated module. Am J Infect Control 44(12):1495-1504

28. Gadsby NJ, Russell CD, McHugh MP, Mark H, Conway Morris A, Laurenson IF, Hill AT, Templeton KE (2016) Comprehensive molecular testing for respiratory pathogens in communityacquired pneumonia. Clin Infect Dis 62(7):817-823

29. Corrado RE, Lee D, Lucero DE, Varma JK, Vora NM. Burden of adult community-acquired, heathcare-associated, hopitalacquired, and ventilator-acquired pneumonia: New York City, 2010 to 2014. Chest. 2017. 152(5), 930-942

30. Quartin AA, Scerpella EG, Puttagunta S, Kett DH (2013) A comparison of microbiology and demographics among patients with healthcare-associated, hospital-acquired, and ventilator-associated pneumonia: A retrospective analysis of 1184 patients from a large, international study. BMC Infect Dis 13:561

31. Ahn JH, Lee KH, Chung JH, Shin KC, Lee CK, Kim HJ, Choi EY (2017) Clinical characteristics and prognostic risk factors of healthcare-associated pneumonia in a Korean tertiary teaching hospital. Medicine (Baltimore) 96(42):e8243

32. Lee H, Park JY, Lee T, Lee YJ, Lim HJ, Park JS, Yoon HI, Lee JH, Lee CT, Cho YJ (2016) Intermediate risk of multidrug-resistant organisms in patients who admitted in intensive care units with healthcare-associated pneumonia. Korean J Intern Med 31(3):525-534

33. Indian Brand Equity Foundation. Healthcare industry in India (2017). Updated July 2017 (Internet). https://www.ibef.org/indus try/healthcare-india.aspx

34. Murray CK, Blyth DM (2017) Acquisition of multidrug-resistant gram negative organisms during travel. Mil Med 182(S2):26-33

35. Kumarasamy KK, Toleman MA, Walsh TR, Bagaria J, Butt F, Balakrishnan R, Chaudhary U, Doumith M, Giske CG, Irfan S, Krishnan P, Kumar AV, Maharjan S, Mushtaq S, Noorie T, Paterson DL, Pearson A, Perry C, Pike R, Rao B, Ray U, Sarma JB, Sharma M, Sheridan E, Thirunarayan MA, Turton J, Upadhyay S, Warner M, Welfare W, Livermore DM, Woodford N (2010) Emergence of a new antibiotic resistance mechanism in India, Pakistan, and the UK: A molecular, biological, and epidemiological study. Lancet Infect Dis 10(9):597-602

36. Fomda BA, Khan A, Zahoor D (2014) NDM-1 (New Delhi metallo beta lactamase-1) producing Gram negative bacilli: emergence and clinical implications. Indian J Med Res 140(5):672-678

37. Liu YY, Wang Y, Walsh TR, Yi LX, Zhang R, Spencer J, Doi Y, Tian G, Dong B, Huang X, Yu LF, Gu D, Ren H, Chen X, Lv L, He D, Zhou H, Liang Z, Liu JH, Shen J (2016) Emergence of 
plasmid-mediated colistin resistance mechanism MCR-1 in animals and human beings in China: a microbiological and molecular biological study. Lancet Infect Dis 16(2):161-168

38. Cilioniz C, Gabarrus A, Ferrer M, Puig de la Bellacasa

J, Rinaudo M, Mensa J, Niederman MS, Torres A (2016)
Community-acquired pneumonia due to multidrug- and non-multidrug-resistant Pseudomonas aeruginosa. Chest 150(2):415-425

\section{Affiliations}

\section{Sandeep Kumar ${ }^{1} \cdot$ Rafi Ahmed Jan $^{1}\left[\right.$ - Bashir Ahmad Fomda ${ }^{2} \cdot$ Roohi Rasool $^{3} \cdot$ Parvaiz Koul $^{1} \cdot$ Sonaullah Shah $^{1}$. Umar Hafiz Khan ${ }^{1}$. Syed Mudasir Qadri ${ }^{1}$. Shariq Rashid Masoodii ${ }^{4}$ Suhail Mantoo ${ }^{1} \cdot$ Mudasir Muzamil $^{1}$}

Sandeep Kumar

drsandeep.neph@gmail.com;

drsandeep_kumar@hotmail.com

Bashir Ahmad Fomda

bashirfomda@yahoo.com

Roohi Rasool

roohi_wani@yahoo.com

Parvaiz Koul

parvaizk@gmail.com

Sonaullah Shah

sonaullah_shah@yahoo.co.in

Umar Hafiz Khan

drumarhafiz@gmail.com

Syed Mudasir Qadri

drsmudasir@yahoo.co.in

Shariq Rashid Masoodi

shariq.masoodi@skims.ac.in
Suhail Mantoo

mantoosuhail@yahoo.com

Mudasir Muzamil

drmmuzamil@gmail.com

1 Department of Internal Medicine (Pulmonary Medicine), Sher I Kashmir Institute of Medical Sciences (SKIMS),

Srinagar, Jammu and Kashmir 190001, India

2 Department of Microbiology, Sher I Kashmir Institute of Medical Sciences (SKIMS), Srinagar, Jammu and Kashmir 190001, India

3 Department of Immunology and Molecular Biology, Sher I Kashmir Institute of Medical Sciences (SKIMS), Srinagar, Jammu and Kashmir 190001, India

4 Department of Endocrinology, Sher I Kashmir Institute of Medical Sciences (SKIMS), Srinagar, Jammu and Kashmir 190001, India 